\title{
Molecular analysis of the gut contents of Harmonia axyridis (Coleoptera: Coccinellidae) as a method for detecting intra-guild predation by this species on aphidophagous predators other than coccinellids
}

\author{
Brecht INGELS ${ }^{1}$, Alexandre AEBI ${ }^{2,3}$, Louis HAUTIER ${ }^{4}$, Thomas VAN LEEUWEN ${ }^{1}$ and Patrick DE ClerCQ ${ }^{1}$ \\ ${ }^{1}$ Laboratory of Agrozoology, Department of Crop Protection, Faculty of Bioscience Engineering, Ghent University, Coupure links \\ 653,9000 Ghent, Belgium; e-mails: brecht.ingels@ugent.be; thomas.vanleeuwen@ugent.be; patrick.declercq@ugent.be \\ ${ }^{2}$ Agroscope Reckenholz-Tänikon, Research Station ART, Reckenholzstrasse 191, 8046 Zürich, Switzerland; \\ e-mail: alexandre.aebi@unine.ch \\ ${ }^{3}$ Laboratory of Soil Biology, University of Neuchâtel, Rue Emile-Argand 11, 2000 Neuchâtel, Switzerland \\ ${ }^{4}$ Biological Control and Plant Genetic Resources Department, Walloon Agricultural Research Centre, Rue de Liroux 2, \\ 5030 Gembloux, Belgium; e-mail: hautier@cra.wallonie.be
}

Key words. Coleoptera, Coccinellidae, Harmonia axyridis, Neuroptera, Chrysopidae, Chrysoperla carnea, Diptera, Syrphidae, Episyrphus balteatus, intraguild predation, gut-content analysis

\begin{abstract}
Several studies have demonstrated that the invasive ladybird Harmonia axyridis is a strong intra-guild predator of native species of ladybird. Laboratory studies have shown that $H$. axyridis can be an intra-guild predator of aphid predators other than coccinellids, including the hoverfly Episyrphus balteatus and lacewing Chrysoperla carnea. However, little is known about the effect of intra-guild predation (IGP) by $H$. axyridis on hoverfly and lacewing populations in the field. In the present study molecular analyses were used to detect the DNA of E. balteatus and C. carnea in the gut contents of H. axyridis. Primers for the syrphid and chrysopid prey were designed and feeding experiments performed to determine how long prey DNA remains detectable in the guts of this ladybird. DNA detection was influenced by the life stage of the predator and species of prey. Meal size did not affect detection time, except when fourth instar individuals of $H$. axyridis were fed 10 eggs or one second instar of $C$. carnea. Predator weight, sex and morpho-type (melanic/non-melanic) did not influence DNA detection. The half-life of the time for which the DNA of the prey remained detectable was calculated for each predator-prey combination, and ranged from 8.9 to $52.4 \mathrm{~h}$. This method can be used to study the ecological importance of IGP by H. axyridis on aphidophagous predators other than coccinellids in the field.
\end{abstract}

\section{INTRODUCTION}

Intra-guild predation (IGP) is a widespread phenomenon, which occurs when one predator consumes another that is competing for the same prey. It differs from classical predation because it reduces the incidence of scramble competition (Polis et al., 1989). IGP occurs in a variety of ecosystems at different trophic levels. It affects the distribution, abundance and evolution of the intraguild predator, intra-guild prey and their common prey (Polis et al., 1989; Arim \& Marquet, 2004). Because of its importance in regulating predator communities, IGP has been investigated extensively in a variety of ecosystems, including systems of aphidophagous predators (reviewed by Lucas, 2005; Hemptinne et al., 2012).

A large number of IGP studies have focused on the harlequin ladybird, Harmonia axyridis (Pallas) (Coleoptera: Coccinellidae). It is native to large parts of Eastern Asia, but has spread at a very fast rate through North America, Europe, and parts of Africa and South America over the past 25 years (Brown et al., 2011b). Its establishment in North America and Europe is believed to have had an adverse effect on certain native species (Convention of Biological Diversity, http://www.cbd.int; Roy et al., 2011). In the UK, Belgium and Switzerland, invasion by $H$. axyridis is associated with the decline in the abun- dance of several native species of ladybird (Brown et al., 2011a; Roy et al., 2012), ostensibly due to direct competition and IGP.

Consequently, IGP involving $H$. axyridis has been widely studied under laboratory conditions (reviewed by Pell et al., 2008). The majority of these studies investigated interactions with other ladybird species. Generally, $H$. axyridis is a strong intra-guild predator, successfully consuming other coccinellid species with which it is paired (e.g. Ware \& Majerus, 2008). There are also studies on intra-guild interactions with predators other than coccinellids. In interactions with the hoverfly Episyrphus balteatus DeGeer (Diptera: Syrphidae) H. axyridis was the intra-guild predator in almost all combinations of life stages. Young larval instars of this hoverfly were especially vulnerable to predation (Putra et al., 2009; Alhmedi et al., 2010; Ingels \& De Clercq, 2011). When paired with larvae of Chrysoperla carnea (Stephens) (Neuroptera: Chrysopidae), fourth instar and adult $H$. axyridis are the intra-guild predator, although third instar lacewing larvae are able to feed on small larvae of this ladybird (Gardiner \& Landis, 2007; Wells, 2011).

Most studies on IGP, including those discussed above, were performed under controlled laboratory conditions, often in Petri dishes or on small potted plants. Such 
experiments are useful for determining the potential outcome of predatory interactions, but the results may not be relevant to field situations (Harwood \& Obrycki, 2005). Therefore, in order to obtain an insight into the importance of IGP for insect communities field studies are crucial.

Predation is one of the most difficult inter-specific interactions to study in the field (Sunderland, 1988; Symondson, 2002). Direct visual observations have been used in some studies (e.g. Rosenheim et al., 1999), but are very time-consuming and likely to disturb the system (Symondson, 2002). To overcome these difficulties, several techniques for post-mortem gut-content analysis of field collected predators have been developed, which have the advantage of revealing past predation events without any form of experimental interference (Sunderland, 1988; Harwood \& Obrycki, 2005). Early application of gut-content analysis consisted of dissection and visual identification of prey remains (Triltsch, 1999; Ricci \& Ponti, 2005). In recent years, predator-prey studies have focused on identifying prey remains in the gut of a predator by using monoclonal antibodies, gas chromatography mass spectrometry (GC-MS) or DNA-based technology (Michaud \& Harwood, 2012). Each technique has its strengths and weaknesses, which have been reviewed by Symondson (2002), Sheppard \& Harwood (2005) and Aebi et al. (2011).

Recently, DNA-based field studies of IGP by $H$. axyridis on native coccinellids have been carried out in soybean fields in Canada (Gagnon et al., 2011b) and on linden trees in eastern England (Thomas et al., 2012). Hautier et al. $(2008,2011)$ used GC-MS to provide evidence of IGP by $H$. axyridis on other ladybirds in potato fields and on linden trees in Belgium. However, there are no field studies on IGP by $H$. axyridis on aphid predators other than coccinellids.

The hoverfly E. balteatus and lacewing C. carnea are both the most widespread species of their family in Europe (McEwen et al., 2001; Stubbs \& Falk, 2002). Furthermore, their larvae are important aphidophagous predators and are used as biological control agents in various agro-ecosystems (Sadeghi \& Gilbert, 2000; McEwen et al., 2001). Because of their wide distribution, both species co-occur with $H$. axyridis in different crops and semi-natural habitats (Alhmedi et al., 2009; Wells, 2011). Thus, $H$. axyridis is likely to interact with both $E$. balteatus and $C$. carnea.

The aim of the present study was to develop a DNAbased gut-content analysis to detect the DNA of E. balteatus and $C$. carnea in the gut of $H$. axyridis, which can be used to determine the incidence of IGP among these species in the field. Factors known to influence the level at which the DNA of prey can be detected (Hosseini et al., 2008) were investigated, including digestion time, meal size and $H$. axyridis developmental stage, weight, sex and morpho-type.

\section{MATERIAL AND METHODS}

\section{Insects}

Adults and larvae of $H$. axyridis were collected in "De Groene Vallei", a public park in which the vegetation consists mainly of maple trees (Acer sp.), in Ghent, Belgium. The individuals collected were used to initiate two laboratory populations. The first consisted of non-melanic succinea individuals (approximately 100), and will hence forth be referred to as the "non-melanic population". Melanic spectabilis and conspicua individuals (approximately 100) were used to start a second population, called the "melanic population" (Osawa \& Nishida, 1992). Non-melanic individuals appearing in the first few laboratory generations of the melanic population were removed. Both populations were reared on frozen Ephestia kuehniella Zeller (Lepidoptera: Pyralidae) eggs, as described by De Clercq et al. (2003). Eggs of E. kuehniella were obtained from Koppert BV (Berkel en Rodenrijs, The Netherlands).

A culture of $E$. balteatus was established with individuals (approximately 50) collected in July 2009 in cabbage fields in Sint-Katelijne-Waver, Beitem and Kruishoutem, Belgium. New field collected individuals were added to the laboratory population in 2010 and 2011 (approximately 30 each year). Adults were kept in Plexiglas cages $(60 \times 60 \times 60 \mathrm{~cm})$ and provided with pollen and honey water. Ground dry honey bee pollen was presented on a tray $(5 \mathrm{~cm}$ in diameter). Honey water was provided by placing a piece of cotton wool previously soaked in water in a dish (5 $\mathrm{cm}$ in diameter). Broad bean plants (Vicia faba L.) infested with pea aphid Acyrthosiphon pisum (Harris) (Hemiptera: Aphididae) were placed in the cages to stimulate the syrphids to oviposit. On hatching larvae were individually transferred to small Petri dishes (5 $\mathrm{cm}$ in diameter, $1.5 \mathrm{~cm} \mathrm{high)}$ and fed ad libitum with pea aphids.

A culture of $C$. carnea was initiated with individuals obtained from Koppert BV. Adults were placed in Petri dishes $(15 \mathrm{~cm}$ in diameter, $2 \mathrm{~cm}$ high) and provided with pollen and honey water (in the same way as the population of E. balteatus). Eggs laid in the Petri dishes were removed every two days. When the eggs hatched the larvae were placed individually in small Petri dishes ( $5 \mathrm{~cm}$ in diameter, $1.5 \mathrm{~cm}$ high) and fed frozen eggs of $E . k u e h-$ niella. All laboratory colonies were maintained at $23 \pm 1{ }^{\circ} \mathrm{C}, 65$ $\pm 5 \% \mathrm{RH}$ and a $16 \mathrm{~L}: 8 \mathrm{D}$ photoperiod.

\section{DNA extraction}

DNA in the $H$. axyridis used in the feeding experiments (see below) was extracted using whole insects in the case of larvae. For adult specimens from these feeding experiments, the elytra, wings and legs were removed prior to extraction. All the other individuals from which DNA was extracted were either starved for $72 \mathrm{~h}$ or had their abdomen removed prior to extraction, to avoid contamination from the gut contents.

DNA was extracted using an EZNA ${ }^{\circledR}$ Insect DNA Isolation Kit (Omega Bio-tek), following the protocol described by the manufacturer, with some minor changes as described below. $350 \mu 1$ of CTL buffer and $25 \mu 1$ of Proteinase K $(20 \mathrm{~g} / \mathrm{l})$ were added to a $1.5 \mathrm{ml}$ micro-centrifuge tube in which the insect was placed. Then, the insects were ground with a pestle and incubated at $60^{\circ} \mathrm{C}$ for 2 to $3 \mathrm{~h}$. Pestles were rinsed with acetone, washed with soap, rinsed with distilled water and autoclaved before use. To remove RNA from the samples, they were incubated at $70^{\circ} \mathrm{C}$ for $10 \mathrm{~min}$ after adding $2 \mu \mathrm{l}$ RNase A. DNA was eluted from the HiBind ${ }^{\circledR}$ DNA column using $100 \mu$ l elution buffer. The micro-centrifuge tubes containing the extracted DNA were stored at $-20^{\circ} \mathrm{C}$ until required. 
TABLE 1. Species (one individual per species) used to test the specificity of the primers selected.

\begin{tabular}{|c|c|c|c|}
\hline Order & Family & Species tested & Origin of sample \\
\hline \multirow[t]{5}{*}{ Diptera } & Syrphidae & Sphaerophoria scripta (Linnaeus) & Belgium \\
\hline & & Eupeodes corollae (Fabricius) & Belgium \\
\hline & & Platycheirus peltatus Meigen & Belgium \\
\hline & & Syrphus ribesii Linnaeus & Belgium \\
\hline & & Syrphus vitripennis Meigen & Belgium \\
\hline \multirow{2}{*}{ Neuroptera } & Chrysopidae & Chrysopa perla Linnaeus & Netherlands \\
\hline & Hemerobiidae & Hemerobius sp. & Belgium \\
\hline \multirow[t]{11}{*}{ Coleoptera } & Coccinellidae & Harmonia quadripunctata (Pontoppidian) & Belgium \\
\hline & & Propylea quatuordecimpunctata (Linnaeus) & Belgium \\
\hline & & Calvia quatuordecimguttata (Linnaeus) & Denmark \\
\hline & & Exochomus quadripustulatus Linnaeus & Belgium \\
\hline & & Adalia bipunctata (Linnaeus) & Denmark \\
\hline & & Adalia decempunctata (Linnaeus) & Denmark \\
\hline & & Coccinella septempunctata Linnaeus & Belgium \\
\hline & & Coccinella undecimpunctata Linnaeus & Belgium \\
\hline & & Hippodamia variegata (Goeze) & Belgium \\
\hline & & Halyzia sedecimguttata (Linnaeus) & Belgium \\
\hline & & Oenopia conglobata (Linnaeus) & Belgium \\
\hline \multirow[t]{6}{*}{ Hemiptera } & Anthocoridae & Anthocoris nemoralis (Fabricius) & United Kingdom \\
\hline & & Anthocoris nemorum (Linnaeus) & United Kingdom \\
\hline & & Orius minutus (Linnaeus) & Belgium \\
\hline & Aphididae & Acyrthosiphon pisum (Harris) & Belgium \\
\hline & & Sitobion avenae (Fabricius) & Belgium \\
\hline & & Periphyllus sp. & Belgium \\
\hline
\end{tabular}

\section{Sequencing and primer design}

Part of the mitochondrial cytochrome oxidase subunit I (COI) gene was targeted for the design of primers for E. balteatus and C. Carnea, because this gene is present in thousands of copies in arthropod cells (Hoy, 1994). The primers also amplified sequences shorter than 250 bp. Amplifying a short DNA sequence of a target gene present in multiple copies in the cell has resulted in an increase in the likelihood of detecting the DNA of prey in the gut of a predator (Zaidi et al., 1999; Agusti et al., 2003).

The COI-region of three individuals from different populations of $E$. balteatus, $C$. carnea and $H$. axyridis was amplified using the universal COI-primers UEA5 and UEA10 in the case of E. balteatus and UEA3 and UEA10 for the other species (Zhang \& Hewitt, 1996), using the PCR conditions described by the authors. The double stranded PCR products were purified using an EZNA ${ }^{\circledR}$ Cycle Pure Kit (Omega Bio-tek) and sequenced by LGC Genomics (Germany). The newly obtained sequences were submitted to GenBank (GenBank ID: JQ715423 to JQ715425 for E. balteatus; JQ715426 to JQ715428 for $C$. carnea; JQ715429, JQ715430 and JQ740172 for H. axyridis). Sequences available in GenBank for E. balteatus (EU241740), C. carnea (AY743794) and H. axyridis (GU073896 and GU073932) were also used.

The obtained COI-sequences were aligned using the BioEdit sequence alignment editor 7.0.5 (Hall, 1999). After identifying areas with species-specific signatures, several primer pairs for both $E$. balteatus and $C$. carnea were designed using the software Primer3 (Rozen \& Skaletsky, 2000). All the primers we designed were then tested for specificity (as described in King et al., 2008) and performance in PCR.

\section{PCR conditions}

All reactions $(50 \mu \mathrm{l})$ were run on a TProfessional standard gradient thermo-cycler (Biometra). The PCR-mix contained a PCR-buffer (20 mmol/1 Tris-HCl pH 8.4, $50 \mathrm{mmol} / 1 \mathrm{KCl}), 2$ $\mathrm{mmol} / 1 \mathrm{MgCl}_{2}, 0.2 \mathrm{mmol} / 1$ of each dNTP, $0.14 \mathrm{mmol} / \mathrm{l}$ of each primer and $2.5 \mathrm{U}$ of Invitrogen ${ }^{\mathrm{TM}}$ Taq DNA polymerase (Life Technologies, California, USA). Each reaction solution contained $5 \mu \mathrm{l}$ of template DNA, extracted as described above. The PCR-cycle was the same for the primers for $E$. balteatus and $C$. carnea. It started with $1 \mathrm{~min}$ and $30 \mathrm{~s}$ at $95^{\circ} \mathrm{C}$, followed by 35 amplification cycles including denaturation at $95^{\circ} \mathrm{C}$ for $30 \mathrm{~s}$, annealing at $55^{\circ} \mathrm{C}$ for $1 \mathrm{~min}$ and elongation at $72^{\circ} \mathrm{C}$ for $30 \mathrm{~s}$. The final elongation was carried out at $72^{\circ} \mathrm{C}$ for $10 \mathrm{~min}$. Two positive (dilutions of 1 part prey DNA in 1 or 100 parts $H$. axyridis DNA) and two negative controls (pure H. axyridis DNA and autoclaved distilled water) were always included. $15 \mu \mathrm{l}$ of the PCR-product was loaded and separated on a $2 \%$ agarose gel stained with ethidium bromide. The PCR-products on the gel were visualized and photographed under UV light.

The universal invertebrate primers $\mathrm{BD} 1$ and $4 \mathrm{~S}$, which amplify the internal transcribed spacer (ITS) region (Bowles \& Mcmanus, 1993) were used to ascertain the presence of DNA of sufficient quality in the samples that did not yield a PCRproduct in the first reaction, in order to avoid false negative results. The PCR-mix contained the same compounds as described above. The PCR-cycle consisted of $2 \mathrm{~min}$ at $95^{\circ} \mathrm{C}$, followed by 30 cycles including denaturation at $95^{\circ} \mathrm{C}$ for $20 \mathrm{~s}$, annealing at $55^{\circ} \mathrm{C}$ for $30 \mathrm{~s}$ and elongation at $72^{\circ} \mathrm{C}$ for $1 \mathrm{~min}$. The final elongation was carried out at $72^{\circ} \mathrm{C}$ for $10 \mathrm{~min}$. Samples that did not yield a PCR-product in this second reaction were discarded.

\section{Specificity tests}

To ensure specificity for the target species, the primers that we designed were tested in two PCR experiments. In the first, six individuals of $E$. balteatus, $C$. carnea and $H$. axyridis that originated from at least three different populations collected in different countries (Belgium, UK, Switzerland and Denmark) were used. In the second, the PCR assays of both E. balteatus and $C$. carnea were tested for cross-reactivity against a number of non-target species (listed in Table 1). We focused on species 
TABLE 2. Name, sequence, annealing temperature (Ta) and amplicon size of the primer pairs (targeting the COI-gene) selected for E. balteatus and C. carnea.

\begin{tabular}{|c|c|c|c|c|}
\hline \multirow{2}{*}{ Species } & \multicolumn{2}{|r|}{ Primers } & \multirow{2}{*}{$\mathrm{T}_{\mathrm{a}}$} & \multirow{2}{*}{ Amplicon size } \\
\hline & Name & Sequence (5' to 3') & & \\
\hline \multirow{2}{*}{ Episyrphus balteatus } & EB.F6 & CTTTCTGCTGGTATTGCTCATGG & \multirow{2}{*}{$55^{\circ} \mathrm{C}$} & \multirow{2}{*}{$160 \mathrm{bp}$} \\
\hline & EB.R5 & CAAATAAAGGTATTCGATCATAAG & & \\
\hline \multirow{2}{*}{ Chrysoperla carnea } & CC.F4 & CGAGCTGAATTAGGTCAACCAG & \multirow{2}{*}{$55^{\circ} \mathrm{C}$} & \multirow{2}{*}{$244 \mathrm{bp}$} \\
\hline & CC.R4 & CTACTATAGAAGAAGCAAGTAATAAAG & & \\
\hline
\end{tabular}

that are expected to co-occur with E. balteatus, C. carnea and H. axyridis in the field (Alhmedi et al., 2009).

\section{Sensitivity test}

To assess the ability of the primers we designed to detect small amounts of DNA of the prey within a large quantity of predator DNA, a sensitivity test was performed. For this test, a series of tenfold dilutions of prey to $H$. axyridis DNA (i.e. 1 part prey to 1 part $H$. axyridis DNA, diluted to 1 part prey to 106 parts $H$. axyridis DNA) was used as a template in PCR-reactions. The diluted samples always contained a total concentration of $200 \mathrm{ng} / \mu \mathrm{l} \mathrm{DNA}$, and only $1 \mu \mathrm{l}$ of this DNAsolution was used per PCR reaction. This kind of test is only a simulation of the natural situation, but provides useful information on the sensitivity of the primers that can be used for determining which primer set to use (Chen et al., 2000; Traugott et al., 2006; Thomas et al., 2012).

\section{Feeding experiments}

In order to determine for how long the DNA of prey species can be detected in the gut of a predator, feeding experiments were conducted with $H$. axyridis as the predator and either $E$. balteatus or C. carnea as prey. For each species of prey there were two experiments. In the first, fourth instar individuals of $H$. axyridis were used within $24 \mathrm{~h}$ of moulting and collected at random from the melanic and non-melanic populations. In the second experiment both melanic and non-melanic adults of $H$. axyridis of both sexes were used in similar proportions. Sex was determined using the method described by McCornack et al. (2007). The adults were approximately 1 week old and had mated.

Prior to the start of each feeding test, the predators were starved for $24 \mathrm{~h}$ in a Petri dish $(9 \mathrm{~cm}$ in diameter, $1.5 \mathrm{~cm} \mathrm{high})$ containing only a piece of moistened paper. Just before the start of the experiment, larvae and adults of $H$. axyridis were weighed on a balance (Sartorius Genius ME $215 \mathrm{P}, \pm 0.01 \mathrm{mg}$ ) and then placed in a ventilated plastic Petri dish $(5 \mathrm{~cm}$ in diameter, $1.5 \mathrm{~cm}$ high). To investigate the effects of meal size and prey developmental stage on the detection of the DNA of the prey, either 5 eggs, 10 eggs or 1 second instar individual of each prey species (E. balteatus or $C$. carnea) were provided as food in each dish. Eggs and larvae of both prey species were weighed $(\mathrm{N}=20)$ to determine the actual mass of each meal. One egg of E. balteatus weighed on average $0.10 \pm 0.01 \mathrm{mg}$, while a second instar of E. balteatus weighed $1.50 \pm 0.12 \mathrm{mg}$. On average the weight of one egg of $C$. carnea was $0.09 \pm 0.002 \mathrm{mg}$, and of a second instar larva $1.21 \pm 0.09 \mathrm{mg}$. Thus, compared to the smallest meal of 5 eggs, meal size doubled in the case of 10 eggs and tripled in the case of a second instar larva for both species of prey.

The eggs of both species of prey used in the experiments were stored at $4^{\circ} \mathrm{C}$ for a maximum 3 days before testing and were less than $24 \mathrm{~h}$ old when transferred to cold storage. Eggs of E. balteatus were presented on a piece of a leaf of broad bean. Eggs of C. carnea were cut from their stalk and placed on the bottoms of the Petri dishes. Second instar individuals of both prey species were used within $24 \mathrm{~h}$ of moulting and starved for $16 \mathrm{~h}$ prior to the test.

The predators were allowed to feed for $30 \mathrm{~min}$, after which the number of eggs consumed was recorded. Predators that ate less than $80 \%$ of the eggs or did not feed on the second instar larvae of either prey were not included in the analysis.

After feeding, individuals were transferred to a new Petri dish (9 $\mathrm{cm}$ in diameter, $1.5 \mathrm{~cm}$ high) containing only a moistened piece of paper. The Petri dishes were placed in a growth chamber at $23 \pm 1{ }^{\circ} \mathrm{C}, 60 \pm 5 \% \mathrm{RH}$ and a $16 \mathrm{~L}: 8 \mathrm{D}$ photoperiod. The predators were allowed to digest their meals for either: 0,2 , $4,6,8,12,18,24$ or $36 \mathrm{~h}$ after which they were killed by immersion and then stored in $70 \%$ ethanol (pre-chilled at $-20^{\circ} \mathrm{C}$ ) at $-20^{\circ} \mathrm{C}$ until the DNA was extracted. For each food type and digestion period, 5 individuals were frozen. Since there was a high probability of detecting the DNA of prey after $36 \mathrm{~h}$ when fourth instar $H$. axyridis fed on C. carnea, a $48 \mathrm{~h}$ digestion period was also investigated for this combination. The samples of adults of $H$. axyridis that had fed on $C$. carnea and then left to digest the meal for $36 \mathrm{~h}$ were not analyzed because the probability of detecting prey DNA was already very low after $24 \mathrm{~h}$.

For each predator-prey combination, the half-life of the period for which the DNA of the prey could be detected was calculated. This value is defined as the time after which the DNA of the prey they have consumed can be detected in only $50 \%$ of cases, and is considered an appropriate standardized measure of the interval for which the DNA remains detectable (Greenstone et al., 2007).

\section{Statistical analysis}

Data was analyzed using SPSS 19.0 (SPSS, 2010). To investigate the influence of different factors on the detection of $E$. balteatus or C. carnea DNA, a generalized linear model was used with a Binomial error distribution and a logit link function (McCullagh \& Nelder, 1989). Analysis always started with a saturated model. Interactions and non-significant main factors were deleted if their significance level was 0.05 or less. For the initial analysis of the whole dataset, the saturated model contained two factors: developmental stage of $H$. axyridis (fourth instar or adult) and species of prey (E. balteatus or C. carnea). When the data was analyzed for each predator-prey combination separately, the saturated model contained three factors in the case of combinations with fourth instar $H$. axyridis: meal size (5 eggs, 10 eggs or 1 second instar), digestion time $(0,2,4,6,8$, $12,24,36$ or $48 \mathrm{~h}$ ) and predator weight. For the experiments with adult $H$. axyridis, the saturated model contained five factors: meal size (5 eggs, 10 eggs or 1 second instar), digestion time $(0,2,4,6,8,12,24,36$ or $48 \mathrm{~h})$, sex (male or female), morpho-type (melanic or non-melanic) and predator weight. The most parsimonious model is reported, using likelihood ratios to ensure model fit. To calculate the detectability half-life of the DNA of the prey, the Probit Analysis procedure in SPSS 19.0 was used. 


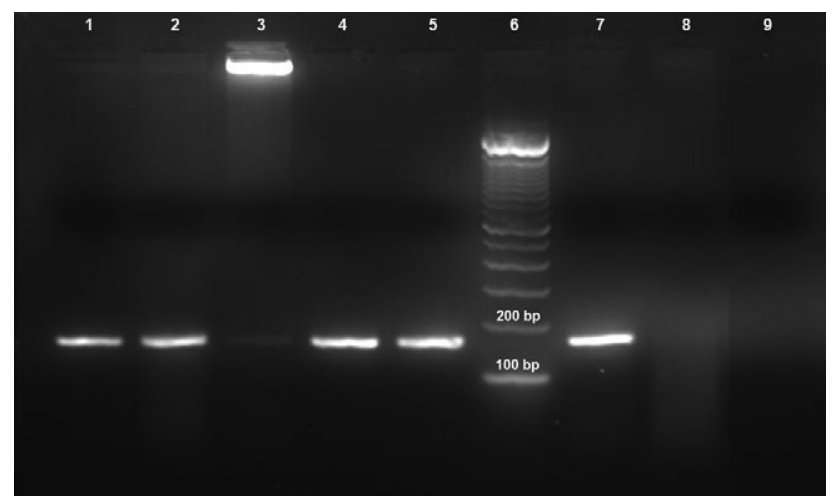

Fig. 1. Agarose gel showing PCR-amplified DNA using primers EB.F6 and EB.R5 (160 bp). lane 1: Sphaerophoria scripta, lane 2: Eupeodes corolla, lane 3: Platycheirus peltatus, lane 4: Syrphus ribesii, lane 5: Syrphus vitripennis, lane 6: molecular size marker (Invitrogen $100 \mathrm{bp}$ ladder), lane 7: positive control (Episyrphus balteatus), lane 8: negative control (Harmonia axyridis), lane 9: negative control $\left(\mathrm{H}_{2} \mathrm{O}\right)$.

\section{RESULTS}

\section{Primer specificity and sensitivity}

The primer pair that gave the best results in terms of both specificity and sensitivity was selected for each species of prey (see Table 2). The pair of primers EB.F6 and EB.R5 was not entirely species-specific, as they also amplified DNA of other species of hoverfly. Except for Platycheirus peltatus Meigen, the bands for the other hoverflies were of similar size and intensity as that for $E$. balteatus (Fig. 1). For primer pair CC.F4 and CC.R4, there was no amplification for any of the species listed in Table 1, indicating it is species specific for $C$. carnea. Both the E. balteatus and C. carnea primer pairs detected their target DNA in a mix of 1 part prey DNA to 104 parts of $H$. axyridis DNA.

\section{Feeding experiments}

In total, 540 samples of $H$. axyridis were analyzed in the PCR assays. All DNA extractions led to high quality DNA as for every sample tested a PCR product was obtained in a reaction with general ITS primers. The number of samples in which prey DNA was detected in each predator-prey combination is listed in Table 3.

Whether the DNA of both of the species of prey was detected depended on the developmental stage of $H$. axyridis $\left(\chi^{2}=14.72 ; \mathrm{df}=1 ; P<0.001\right.$ and $\chi^{2}=68.03 ; \mathrm{df}=$ $1 ; P<0.001$ for E. balteatus and C. carnea, respectively). The DNA of the prey was detected for longer in fourth instar than adult $H$. axyridis. Furthermore, the species of prey had a significant effect on the detection of the DNA of the prey in fourth instar and adult $H$. axyridis $\left(\chi^{2}=\right.$ 9.89; df $=14 ; P=0.002$ and $\chi^{2}=10.41 ; \mathrm{df}=1 ; P=$ 0.001 , respectively). The level of detection was lower for $E$. balteatus than $C$. carnea in experiments with fourth instar $H$. axyridis and the reverse in experiments with adults. Because of the differences in detection success in the different predator-prey combinations, the data for each combination were analyzed separately.

\section{Feeding experiments with fourth instar $H$. axyridis}

Mean predator weight $( \pm \mathrm{SE}$ ) before feeding was 18.99 $\pm 0.30 \mathrm{mg}$ and $19.40 \pm 0.27 \mathrm{mg}$ when E. balteatus and $C$. carnea were the prey, respectively. When E. balteatus was the prey, no interactions were found between factors $\left(\chi^{2}=0.99 ; \mathrm{df}=1\right.$ or $2 ; P=0.610$ for all contrasts $)$. Neither meal size nor predator weight affected the detection of syrphid DNA $\left(\chi^{2}=3.81 ; \mathrm{df}=2 ; P=0.149\right.$ and $\chi^{2}=$ $0.003 ; \mathrm{df}=1 ; P=0.956$, respectively). In contrast, the detection of syrphid DNA was significantly dependent on how long ago it was ingested $\left(\chi^{2}=41.67\right.$; df $=1 ; P<$ $0.001)$. DNA of E. balteatus could be detected in 80 to

TABLE 3. Number of positive samples (out of 5) in which the DNA of prey was detected in each predator-prey combination and different digestion periods. L2 = second instar.

\begin{tabular}{|c|c|c|c|c|c|c|c|}
\hline \multirow{2}{*}{ H. axyridis } & \multirow{2}{*}{$\begin{array}{c}\text { Digestion } \\
\text { time }(\mathrm{h})\end{array}$} & \multicolumn{3}{|c|}{ E. balteatus } & \multicolumn{3}{|c|}{ C. carnea } \\
\hline & & 5 eggs & 10 eggs & $1 \mathrm{~L} 2$ & 5 eggs & 10 eggs & $1 \mathrm{~L} 2$ \\
\hline \multirow[t]{10}{*}{ Fourth instar } & 0 & 5 & 5 & 5 & 5 & 5 & 5 \\
\hline & 2 & 5 & 5 & 5 & 5 & 5 & 5 \\
\hline & 4 & 5 & 5 & 4 & 5 & 5 & 5 \\
\hline & 6 & 4 & 4 & 4 & 5 & 5 & 5 \\
\hline & 8 & 5 & 5 & 5 & 5 & 5 & 3 \\
\hline & 12 & 5 & 5 & 3 & 5 & 5 & 4 \\
\hline & 18 & 4 & 4 & 2 & 2 & 4 & 4 \\
\hline & 24 & 2 & 2 & 1 & 5 & 3 & 3 \\
\hline & 36 & 2 & 1 & 2 & 3 & 5 & 2 \\
\hline & 48 & - & - & - & 2 & 4 & 1 \\
\hline \multirow[t]{9}{*}{ Adult } & 0 & 5 & 5 & 5 & 5 & 5 & 5 \\
\hline & 2 & 5 & 5 & 5 & 5 & 5 & 5 \\
\hline & 4 & 4 & 5 & 3 & 4 & 5 & 5 \\
\hline & 6 & 4 & 5 & 5 & 3 & 2 & 2 \\
\hline & 8 & 3 & 4 & 2 & 1 & 2 & 3 \\
\hline & 12 & 3 & 0 & 4 & 1 & 2 & 0 \\
\hline & 18 & 2 & 0 & 3 & 0 & 1 & 0 \\
\hline & 24 & 1 & 2 & 0 & 0 & 0 & 1 \\
\hline & 36 & 0 & 0 & 1 & - & - & - \\
\hline
\end{tabular}



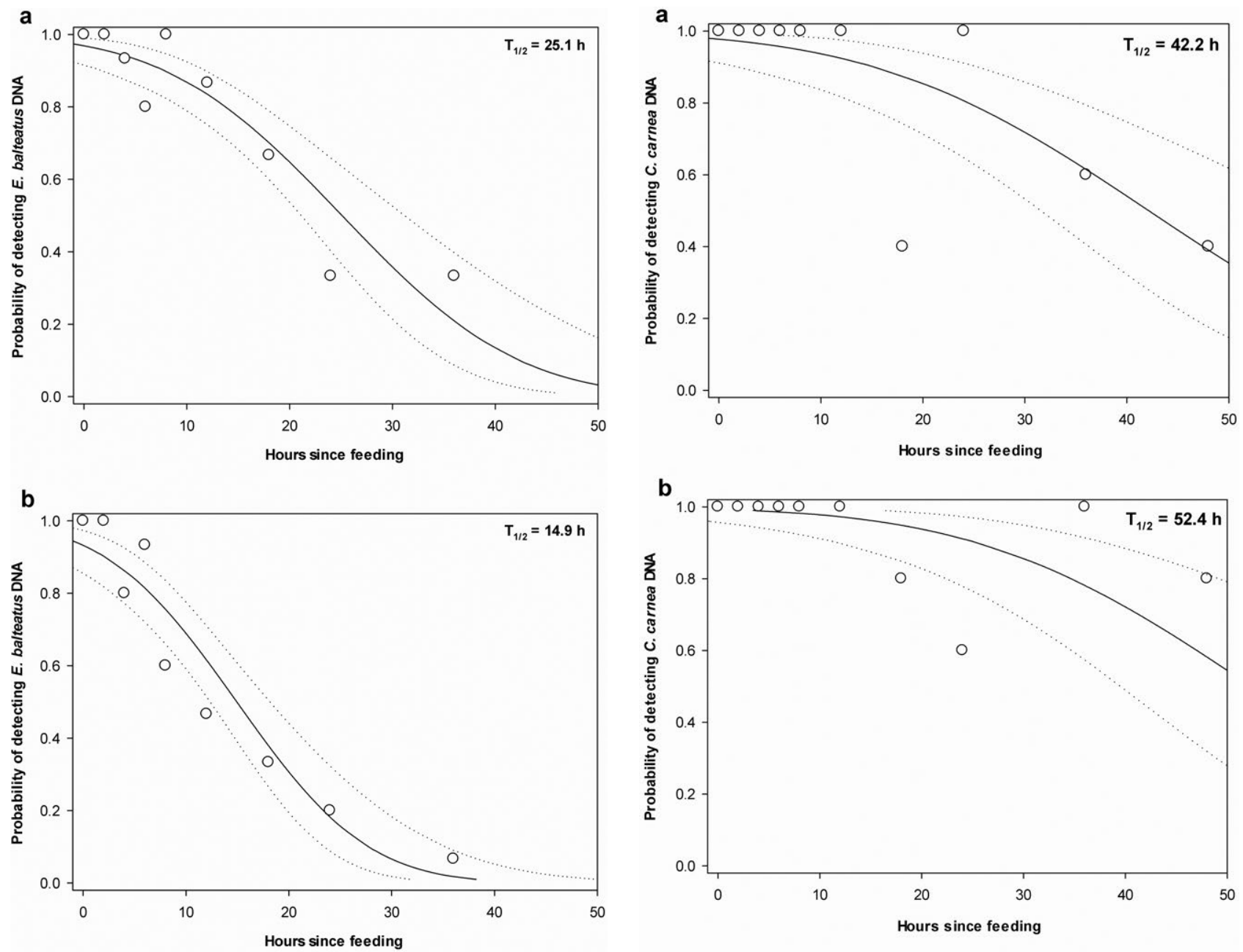

Fig. 2. Results of the feeding experiments in which E. balteatus was the prey and a: fourth instar $H$. axyridis and b: adult $H$. axyridis the predator. Circles are PCR data; $\mathrm{n}=15$ individual predators used for each data point. The solid lines represent the fitted probit model, the dotted lines the $95 \%$ confidence limits. T1/2: half-life of the period for which the DNA of the prey could be detected.

$100 \%$ of cases within up to $12 \mathrm{~h}$ of digestion decreasing to between 20 to $40 \%$ after $36 \mathrm{~h}$.

When $C$. carnea was the prey, there were no significant interactions between factors $\left(\chi^{2}=2.96 ; \mathrm{df}=1\right.$ or $2 ; P=$ 0.228 for all contrasts). The detection of the DNA of $C$. carnea was not affected by the weight of the predator $\left(\chi^{2}\right.$ $=1.26 ; \mathrm{df}=1 ; P=0.261)$, but there was a significant effect of meal size. When one second instar of the chrysopid was eaten, the level of detection was lower than when 10 eggs were eaten $\left(\chi^{2}=7.34\right.$; df $=1 ; P=$ $0.007)$. There was no difference between one second instar and 5 eggs $\left(\chi^{2}=2.40 ; \mathrm{df}=1 ; P=0.121\right)$ or between the two egg treatments $\left(\chi^{2}=1.89\right.$; df $=1 ; P=$ 0.169 ). Again, the period for which the prey was digested significantly affected the level of detection of the DNA of the prey $\left(\chi^{2}=31.07\right.$;f $\left.=1 ; P<0.001\right)$. In this case, DNA of $C$. carnea could be detected in 80 to $100 \%$ of cases up to $12 \mathrm{~h}$ after ingestion and there was still a $40 \%$ chance of detection after $48 \mathrm{~h}$.

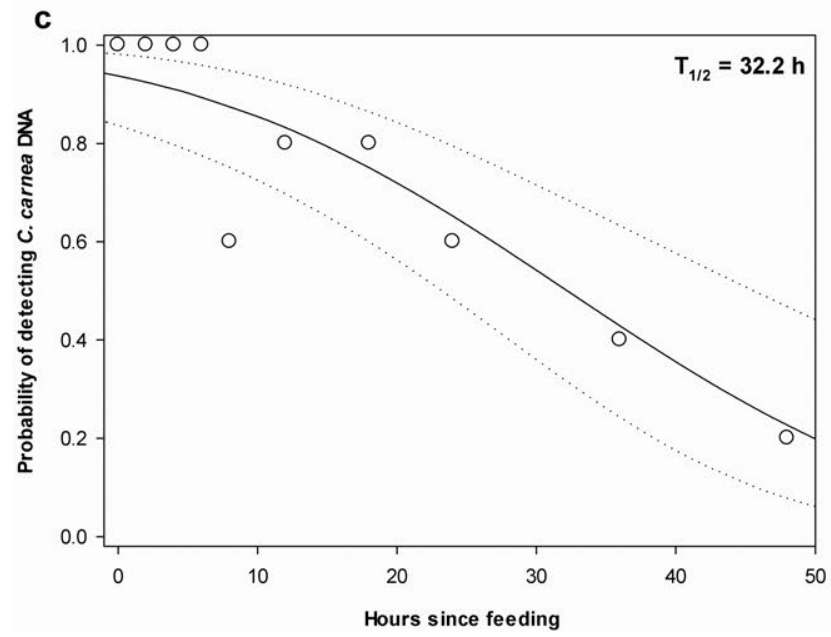

Fig. 3. Results of the feeding experiments in which a fourth instar $H$. axyridis was the predator and a: 5 eggs; b: 10 eggs; c: one second instar of $C$. carnea the prey. Circles are PCR data; $n$ $=5$ individual predators used for each data point. The solid lines represent the fitted probit model, the dotted lines the $95 \%$ confidence limits. T1/2: half-life of the period for which the DNA of the prey could be detected.

Feeding experiments with adult $H$. axyridis

Mean predator weight $( \pm \mathrm{SE})$ before feeding was 37.11 $\pm 0.57 \mathrm{mg}$ and $35.39 \pm 0.67 \mathrm{mg}$ for adult $H$. axyridis fed E. balteatus and C. carnea, respectively. Results for 
approximately equal numbers of males and females, and melanic and non-melanic adults were analyzed (121 males and 134 females, and 137 non-melanic and 118 melanic individuals).

When $E$. balteatus was the prey, there were no interactions between factors $\left(\chi^{2}=3.13\right.$; df $=1$ or $2 ; P=0.077$ for all contrasts $)$ and no effect of predator weight $\left(\chi^{2}=\right.$ $0.04 ; \mathrm{df}=1 ; P=0.840)$, sex $\left(\chi^{2}=1.76 ; \mathrm{df}=1 ; P=0.184\right)$ or morpho-type $\left(\chi^{2}=0.66 ; \mathrm{df}=1 ; P=0.417\right)$. Furthermore, meal size did not affect the level of detection of the DNA of the prey $\left(\chi^{2}=0.48 ; \mathrm{df}=2 ; P=0.787\right)$, although there was again a strong effect of the length of the period since the prey was ingested $\left(\chi^{2}=65.50 ; \mathrm{df}=1 ; P<\right.$ $0.001)$. Detection in 80 to $100 \%$ of the cases was obtained within up to $6 \mathrm{~h}$ of digestion, whereas after $24 \mathrm{~h}$, it was only $20 \%$ of cases.

When adult $H$. axyridis were fed $C$. carnea there were no interactions between factors $\left(\chi^{2}=4.89 ; \mathrm{df}=1\right.$ or $2 ; P$ $=0.087$ for all contrasts $)$. Again, there was no effect of predator weight $\left(\chi^{2}=0.83 ; \mathrm{df}=1 ; P=0.361\right)$, sex $\left(\chi^{2}=\right.$ $0.50 ; \mathrm{df}=1 ; P=0.481)$ morpho-type $\left(\chi^{2}=0.13 ; \mathrm{df}=1 ; P\right.$ $=0.716)$ or meal size $\left(\chi^{2}=1.06 ; \mathrm{df}=2 ; P=0.590\right)$. Period of time for which the prey had been digested strongly affected the level of detection of the DNA of the prey $\left(\chi^{2}=61.08\right.$; df $\left.=1 ; P<0.001\right)$; it could only be detected in 80 to $100 \%$ of $H$. axyridis adults within $4 \mathrm{~h}$ of digestion and only in about $20 \%$ after $12 \mathrm{~h}$.

The half-life of the period for which the DNA of prey can be detected

The half-life of the period for which the DNA of the prey can be detected for each predator-prey combination, was calculated using probit regression. Because there was no influence of meal size for both treatments with $E$. balteatus and for the treatment with adult $H$. axyridis and $C$. carnea as prey, the data for different meals (5 eggs, 10 eggs or one second instar) were pooled and only one probit model was calculated. Since meal size affected the level of detection of the DNA of the prey in the treatment in which fourth instar $H$. axyridis were fed $C$. carnea, the half-life was calculated for each meal size.

The probit models for E. balteatus represent the data well $\left(\chi^{2}=9.96 ; \mathrm{df}=7 ; \mathrm{p}=0.191\right.$ for fourth instar and $\chi^{2}$ $=10.26 ; \mathrm{df}=7 ; \mathrm{p}=0.175$ for adult $H$. axyridis) (Fig. 2 ). From these models, the half-life (T1/2) of the period for the DNA of the prey can be detected was $25.1 \mathrm{~h}$ for fourth instar and $14.9 \mathrm{~h}$ for adult $H$. axyridis. For the treatments in which $C$. carnea was the prey the estimated models represent the data well $\left(\chi^{2}=29.43 ; \mathrm{df}=26 ; \mathrm{p}=\right.$ 0.292 for fourth instar and $\chi^{2}=7.93 ; \mathrm{df}=6 ; \mathrm{p}=0.244$ for adult $H$. axyridis) (Figs 3 and 4). The half-life for fourth instar $H$. axyridis was $42.2,52.4$ and $32.2 \mathrm{~h}$ for 5 eggs, 10 eggs or one second instar larva of C. carnea, respectively. For adult $H$. axyridis, the half-life was estimated to be $8.9 \mathrm{~h}$ regardless of meal size or life stage of the prey.

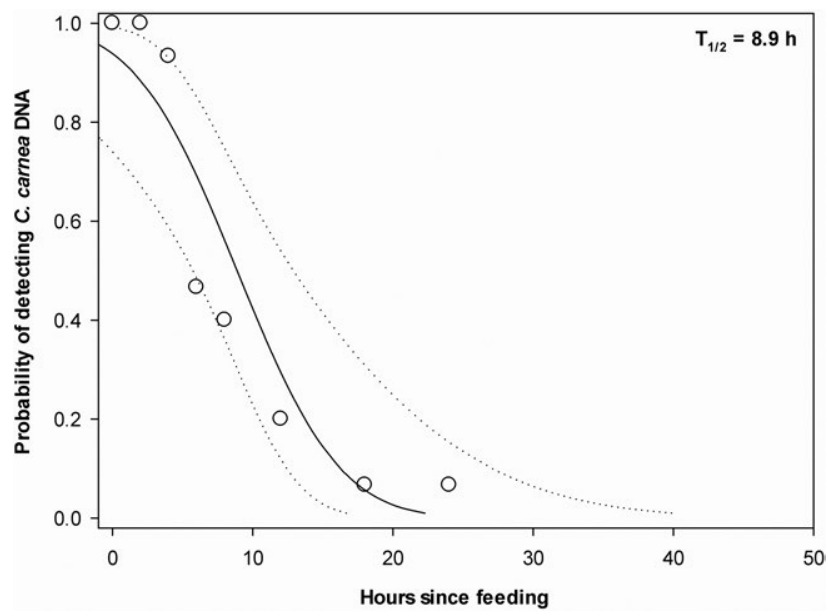

Fig. 4. Results of the feeding experiments in which an adult $H$. axyridis was the predator and C. carnea the prey. Circles are PCR data; $\mathrm{n}=15$ individual predators used for each data point. The solid line represents the fitted probit model, the dotted lines the $95 \%$ confidence limits. T1/2: half-life of the period for which the DNA of the prey could be detected.

\section{DISCUSSION}

If DNA-based gut-content analysis is to be successfully used in the field the primers need to be both specific and sensitive (King et al., 2008). Although the primers for $C$. carnea fulfilled these requirements, those for E. balteatus were not entirely species-specific, as they also amplified DNA of a few other species of hoverfly. Nonetheless, these primers may still be useful for assessing the incidence of IGP in the field under certain circumstances, for example, if E. balteatus outnumbers other hoverfly species at the investigated site. This is the case in several crops in Belgium where E. balteatus often represents 68 to $82 \%$ of all Syrphidae (Alhmedi et al., 2009). Furthermore, species identity could be confirmed by sequencing the PCR-product of a positive sample and comparing this sequence with an alignment of COI sequences obtained from all the species of hoverfly present. This approach, which has been used in studies on marine invertebrates (Blankenship \& Yayanos, 2005), would allow an individual of $H$. axyridis to be screened for the presence of different species of intra-guild prey in its gut using a single PCR reaction, a single sequencing reaction and comparing the sequence using a reference barcode system. Using species-specific primers, several subsequent PCR-reactions or a multiplex PCR-assay (e.g. Harper et al., 2005) are needed to obtain the same result.

Both the E. balteatus and C. carnea primer pairs were able to detect their target DNA in a mixture of 1 part prey DNA to $10^{4}$ parts $H$. axyridis DNA, which corresponds to a sensitivity of approximately $20 \mathrm{pg}$ of prey DNA per PCR reaction. This represents an intermediate sensitivity level, as other studies report primer pairs with higher sensitivity by a factor 2 to $10^{3}$ (Chen et al., 2000; Traugott et al., 2006; Thomas et al., 2012). However, when considering the weight of both the predator and prey, there was a maximum difference of a factor 80 (when an adult of $H$. axyridis, approximately $36 \mathrm{mg}$, consumed 5 eggs of $C$. 
carnea, approximately $0.45 \mathrm{mg}$ ). Taking into account that fresh weight is not a perfect predictor of DNA content and the amount of prey DNA decreases over time, this primer sensitivity of $1: 10^{4}$ is still believed to be sufficient to reliably detect prey DNA in the gut of $H$. axyridis within the time frames identified.

Our results indicate that the relationship between the detection of prey DNA and digestion time is negatively exponential. This is in agreement with similar studies on different predator groups (e.g. Agusti et al., 2003; Hosseini et al., 2008). The half-life of the period for which prey DNA could be detected for each predator-prey combination ranged from 8.9 to $52.4 \mathrm{~h}$; the long half-life for fourth instar $H$. axyridis feeding on $C$. carnea indicates it is possible to detect relatively rare predation events (Gagnon et al., 2011a). However, long detection periods could obscure the frequency of predatory events in the field, since recent feeding events are not distinguishable from older ones, and could lead to overestimation of predation rates. Relatively short detection periods, like the ones found for the other predator-prey combinations in this study, facilitate a clearer interpretation of field data (Hagler \& Naranjo, 1997; Sheppard \& Harwood, 2005).

When comparing detection times of prey DNA in the gut of different Coccinellidae, McMillan et al. (2007) argued that the half-life of the period for which prey DNA can be detected is specific for each predator-prey combination, rather than specific for a particular predator or prey. This was confirmed by Gagnon et al. (2011a), who used this method to investigate IGP interactions between different ladybirds, including $H$. axyridis. Despite close taxonomic relations between the different predators and prey, the half-life of the period for which the DNA of the prey could be detected recorded in the latter study ranged from 5.2 to $19.3 \mathrm{~h}$. In our study, the level of detection of the DNA of prey also differed for the different species of prey, supporting the conclusion of McMillan et al. (2007) and Gagnon et al. (2011a) that detection times cannot be generalized even if predators and prey are closely related and DNA fragments from the same region and of similar length are targeted.

One interesting finding of this study was that the level of detection of the DNA of prey over time declined faster for adult than fourth instar $H$. axyridis. In contrast to our findings, Hoogendoorn \& Heimpel (2001) found no effect of predator stage on the detection of prey DNA for the ladybird Coleomegilla maculata De Geer (Coleoptera: Coccinellidae) fed eggs of Ostrinia nubilalis (Hübner) (Lepidoptera: Crambidae). Greenstone et al. (2010) report a difference in half-life of the period for which the DNA of prey can be detected in adults and immature stages of several predators, including C. maculata, fed one egg of Leptinotarsa decemlineata Say (Coleoptera: Chrysomelidae), however coccinellid larvae digested the egg DNA more rapidly than adults, which is the opposite of what we found. This strengthens our assumption that the level of detection of prey DNA is predator-, prey- and life stage-specific. This also supports the contention that coc- cinellid adults and larvae have different digestive capabilities and nutritional requirements (Michaud, 2005).

The results from our study and that of Greenstone et al. (2010) indicate that, at least in some cases, the rate of digestion of larval and adult ladybirds can differ. This may be explained by the different feeding mode of ladybird larvae and adults. In contrast to adults, digestion by the larvae of most predatory coccinellids is extra-oral and characterized by periodic regurgitation of fluid into the chewed up prey and the sucking back of the pre-digested prey (Hodek \& Honek, 1996). Further Lundgren \& Weber (2010) show that the rate of digestion of certain foods increases during larval development in $C$. maculata, which indicates a change in the quantity or quality of the digestive enzymes. Differences in the composition of the digestive enzymes of fourth instar and adult individuals may thus also account for the different rates of digestion rates recorded in this study.

In general, there was no influence of meal size on the detection of $E$. balteatus or C. carnea DNA in the gut of $H$. axyridis. Only when fourth instar larvae were fed $C$. carnea did meal size affect the level of detection. In most studies that use PCR to detect prey DNA in the guts of predators, the amount of prey eaten did not affect the detection of prey DNA (Zaidi et al., 1999; Hoogendoorn \& Heimpel, 2001; Juen \& Traugott, 2005). In contrast, Weber \& Lundgren (2009) found a significant relation between the quantity of target DNA detected and the number of $L$. decemlineata eggs consumed by $C$. maculata when using quantitative PCR. It thus appears that, due to its high sensitivity, conventional PCR cannot be used to measure meal-size-related differences in prey DNA, at least not for the small range of meal sizes used in the present study. The single predator-prey combination in which we found an influence of meal size was also the combination for which the DNA of the prey was detectable for the longest and probably reflects the increased statistical power to separate digestion curves under these circumstances. The fact that the level of detection of the DNA of the prey was lower after the consumption of a single second instar of C. carnea than 10 eggs, despite the former being $30 \%$ heavier, may be because the larvae were not completely consumed. That is, the amount of DNA ingested was lower and therefore the detection time would have been shorter. Furthermore, the relatively low number of replicates could also have contributed to the observed effect of meal size.

Despite the many advantages of using molecular gutcontent analysis to investigate predator-prey relationships and IGP in the field (Aebi et al., 2011), this method has limitations. In addition to the factors investigated in this study, temperature, time for which the predators are starved and what they eat subsequently are reported to affect the level at which prey can be detected (Hosseini et al., 2008; Weber \& Lundgren, 2009). Furthermore, this technique cannot discriminate primary and secondary predation (Sheppard et al., 2005), scavenging behaviour (Juen \& Traugott, 2005) or prey DNA obtained via cannibalism (Sheppard \& Harwood, 2005). 
The method of DNA-based gut-content analysis developed in this study may improve our understanding of the ecological importance of IGP by this invasive ladybird on populations of both $E$. balteatus and $C$. carnea in the field. As a first in-field validation of this method, larvae of $H$. axyridis, mainly collected from lime trees (Tilia $\mathrm{x}$ europaea L.) in different European countries, were analyzed using the molecular markers developed in this study (Brown et al., in prep.). Approximately 180 individuals of $H$. axyridis were tested, with detection rates varying between 1.1 and $2.8 \%$. The knowledge obtained from this and future field studies may also assist in unraveling the mechanisms underlying the invasive success of $H$. axyridis.

ACKNOWLEDGEMENTS. The funding for this project came from a grant from the Research Foundation - Flanders (FWO Vlaanderen) awarded to B. Ingels. T. Van Leeuwen is a postdoctoral fellow of the Research Foundation - Flanders. The authors would like to thank P. Brown and A. Howe for supplying insect samples, F. Bigler and F. Widmer for providing access to research infrastructures at ART, and A. Thomas and R. Zindel for helpful suggestions.

\section{REFERENCES}

Aebi A., Brown P.M.J., De Clerce P., Hautier L., Howe A., Ingels B., Ravn H.P., Sloggett J.J., Zindel R. \& Thomas A. 2011: Detecting arthropod intraguild predation in the field. BioControl 56: 429-440.

Agusti N., Shayler S.P., Harwood J.D., Vaughan I.P., SunderLAND K.D. \& Symondson W.O.C. 2003: Collembola as alternative prey sustaining spiders in arable ecosystems: Prey detection within predators using molecular markers. - Mol. Ecol. 12: 3467-3475.

Alhmedi A., Haubruge E. \& Francis F. 2009: Effect of stinging nettle habitats on aphidophagous predators and parasitoids in wheat and green pea fields with special attention to the invader Harmonia axyridis Pallas (Coleoptera: Coccinellidae). - Entomol. Sci. 12: 349-358.

Alhmedi A., Haubruge E. \& Francis F. 2010: Intraguild interactions and aphid predators: Biological efficiency of Harmonia axyridis and Episyrphus balteatus. - J. Appl. Entomol. 134: $34-44$.

Arim M. \& Marquet P.A. 2004: Intraguild predation: A widespread interaction related to species biology. - Ecol. Lett. 7: 557-564.

Blankenship L.E. \& Yayanos A.A. 2005: Universal primers and PCR of gut contents to study marine invertebrate diets. Mol. Ecol. 14: 891-899.

Bowles J. \& MCMAnus D.P. 1993: Rapid discrimination of Echinococcus species and strains using a polymerase chain reaction-based rflp method. - Mol. Biochem. Parasit. 57: 231-240.

Brown P.M.J., Frost R., Doberski J., Sparks T., Harrington R. \& Roy H.E. 2011a: Decline in native ladybirds in response to the arrival of Harmonia axyridis: Early evidence from england. - Ecol. Entomol. 36: 231-240.

Brown P.M.J., Thomas C.E., Lombaert E., JefFries D.L., Estoup A. \& HandLey L.J.L. 2011b: The global spread of Harmonia axyridis (Coleoptera: Coccinellidae): Distribution, dispersal and routes of invasion. - BioControl 56: 623-641.

Chen Y., Giles K.L., Payton M.E. \& Greenstone M.H. 2000: Identifying key cereal aphid predators by molecular gut analysis. — Mol. Ecol. 9: 1887-1898.
De Clerce P., Peeters I., Vergauwe G. \& Thas O. 2003: Interaction between Podisus maculiventris and Harmonia axyridis, two predators used in augmentative biological control in greenhouse crops. - BioControl 48: 39-55.

Gagnon A.E., Doyon J., Heimpel G.E. \& Brodeur J. 2011a: Prey DNA detection success following digestion by intraguild predators: Influence of prey and predator species. - Mol. Ecol. Resour. 11: 1022-1032.

Gagnon A.E., Heimpel G.E. \& Brodeur J. 2011b: The ubiquity of intraguild predation among predatory arthropods. - Plos One 6(11): e28061. doi:10.1371/journal.pone.0028061.

GARDINER M.M. \& LANDIS D.A. 2007: Impact of intraguild predation by adult Harmonia axyridis (Coleoptera: Coccinellidae) on Aphis glycines (Hemiptera: Aphididae) biological control in cage studies. - Biol. Contr. 40: 386-395.

Greenstone M.H., Rowley D.L., Weber D.C., Payton M.E. \& Hawthorne D.J. 2007: Feeding mode and prey detectability half-lives in molecular gut-content analysis: An example with two predators of the colorado potato beetle. - Bull. Entomol. Res. 97: 201-209.

Greenstone M.H., Szendrei Z., Payton M.E., Rowley D.L., Coudron T.C. \& Weber D.C. 2010: Choosing natural enemies for conservation biological control: Use of the prey detectability half-life to rank key predators of colorado potato beetle. - Entomol. Exp. Appl. 136: 97-107.

HAGLER J.R. \& NARANJo S.E. 1997: Measuring the sensitivity of an indirect predator gut content elisa: Detectability of prey remains in relation to predator species, temperature, time, and meal size. - Biol. Contr. 9: 112-119.

HALl T.A. 1999: Bioedit: A user-friendly biological sequence alignment editor and analysis program for windows 95/98/nt. — Nucl. Acids Symp. Ser. 41: 95-98.

Harper G.L., King R.A., Dodd C.S., Harwood J.D., Glen D.M., Bruford M.W. \& Symondson W.O.C. 2005: Rapid screening of invertebrate predators for multiple prey DNA targets. Mol. Ecol. 14: 819-827.

HaRwood J.D. \& OBRYCKi J.J. 2005: Quantifying aphid predation rates of generalist predators in the field. - Eur. J. Entomol. 102: 335-350.

Hautier L., Gregoire J.C., de Schaumers J., San Martin y Gomez G., Callier P., Jansen J.P. \& de Biseau J.C. 2008: Intraguild predation by Harmonia axyridis on coccinellids revealed by exogenous alkaloid sequestration. - Chemoecology 18: 191-196.

Hautier L., San Martin y Gomez G., Callier P., de Biseau J.C. \& Gregoire J.C. 2011: Alkaloids provide evidence of intraguild predation on native coccinellids by Harmonia axyridis in the field. - Biol. Invasions 13: 1805-1814.

Hemptinne J.L., Magro A., Saladin C. \& Dixon A.F.G. 2012: Role of intraguild predation in aphidophagous guilds. $-J$. Appl. Entomol. 136: 161-170.

Hodek I. \& HoneK A. 1996: Ecology of Coccinellidae. Kluwer, Dordrecht, Boston, London, $464 \mathrm{pp}$.

Hoogendoorn M. \& Heimpel G.E. 2001: PCR-based gut content analysis of insect predators: Using ribosomal its-1 fragments from prey to estimate predation frequency. - Mol. Ecol. 10: 2059-2067.

Hosseini R., Schmidt O. \& Keller M.A. 2008: Factors affecting detectability of prey DNA in the gut contents of invertebrate predators: A polymerase chain reaction-based method. Entomol. Exp. Appl. 126: 194-202.

Hoy M.A. 1994: Insect Molecular Genetics: An Introduction to Principals and Applications. Academic Press, San Diego, CA, $546 \mathrm{pp}$.

Ingels B. \& De Clerce P. 2011: Effect of size, extraguild prey and habitat complexity on intraguild interactions: A case 
study with the invasive ladybird Harmonia axyridis and the hoverfly Episyrphus balteatus. - BioControl 56: 871-882.

Juen A. \& Traugott M. 2005: Detecting predation and scavenging by DNA gut-content analysis: A case study using a soil insect predator-prey system. - Oecologia 142: 344-352.

King R.A., Read D.S., Traugott M. \& Symondson W.O.C. 2008: Molecular analysis of predation: A review of best practice for DNA-based approaches. - Mol. Ecol. 17: 947-963.

LUCAS E. 2005: Intraguild predation among aphidophagous predators. - Eur. J. Entomol. 102: 351-363.

Lundgren J.G. \& Weber D.C. 2010: Changes in digestive rate of a predatory beetle over its larval stage: Implications for dietary breadth. - J. Insect Physiol. 56: 431-437.

McCornack B.P., Кoch R.L. \& Ragsdale D.W. 2007: A simple method for in-field sex determination of the multicolored asian lady beetle Harmonia axyridis. - J. Insect Sci. 7: 1-12.

McCullagh P. \& Nelder J. 1989: Generalized Linear Models. Chapman and Hall, London, $551 \mathrm{pp}$.

McEwen P., New T.R. \& Whittington A.E. 2001: Lacewings in the Crop Environment. Cambridge University Press, Cambridge, $546 \mathrm{pp}$.

McMillan S., Kuusk A.K., Cassel-Lundhagen A. \& Ekbom B. 2007: The influence of time and temperature on molecular gut content analysis: Adalia bipunctata fed with Rhopalosiphum padi. - Insect Sci. 14: 353-358.

Michaud J.P. 2005: On the assessment of prey suitability in aphidophagous Coccinellidae. - Eur. J. Entomol. 102: 385-390.

Michaud J.P. \& HaRwood J.D. 2012: Quantifying the impact of Coccinellids on their prey. In Hodek I., van Emden H.F. \& Honek A. (eds): Ecology and Behaviour of the Ladybird Beetles. Blackwell, Oxford, pp. 465-487.

OsawA N. \& NISHIDA T. 1992: Seasonal variation in elytral color polymorphism in Harmonia axyridis (the ladybird beetle): The role of non-random mating. - Heredity 69: 297-307.

Pell J.K., Baverstock J., Roy H.E., Ware R.L. \& Majerus M.E.N. 2008: Intraguild predation involving Harmonia axyridis: A review of current knowledge and future perspectives. - Biocontrol 53: 147-168.

Polis G.A., Myers C.A. \& Holt R.D. 1989: The ecology and evolution of intraguild predation: Potential competitors that eat each other. - Annu. Rev. Ecol. Syst. 20: 297-330.

Putra N.S., Yasuda H. \& Sato S. 2009: Oviposition preference of two hoverfly species in response to risk of intraguild predation. - Appl. Entomol. Zool. 44: 29-36.

Ricci C. \& PonTi L. 2005: Seasonal food of Ceratomegilla notata (Coleoptera: Coccinellidae) in mountain environments of northern Italian Alps. - Eur. J. Entomol. 102: 527-530.

Rosenheim J.A., Limburg D.D. \& Colfer R.G. 1999: Impact of generalist predators on a biological control agent, Chrysoperla carnea: Direct observations. - Ecol. Appl. 9: 409-417.

Roy H.E., De Clerce P., Lanwson Handley L.J., Poland R.L., Sloggett J.J. \& WAJNBERG E. 2011: Alien arthropod predators and parasitoids: an ecological approach. - BioControl 56: 375-382.

Roy H.E., Adriaens T., Isaac N.J.B., Kenis M., Onkelinx T., San Martin G., Brown P.M.J., Hautier L., Poland R., Roy D.B., Comont R., Eschen R., Frost R., Zindel R., Van Vlaenderen J., Nedved O., Ravn H.P., Grégoire J.C., de
BISEAU J.C. \& MAES D. 2012: Invasive alien predator causes rapid declines of native european ladybirds. - Divers. Distrib. 18: 717-725.

Rozen S. \& Skaletsky H. 2000: Primer3 on the www for general users and biologist programmers. In Krawetz S. \& Misener S. (eds): Bioinformatics Methods and Protocols: Methods in Molecular Biology. Humana Press, Totowa, NJ, pp. 303-386.

SAdEghi H. \& Gilbert F. 2000: Aphid suitability and its relationship to oviposition preference in predatory hoverflies. J. Anim. Ecol. 69: 771-784.

SHEPPARD S.K. \& HaRwood J.D. 2005: Advances in molecular ecology: Tracking trophic links through predator-prey foodwebs. - Funct. Ecol. 19: 751-762.

Sheppard S.K., Bell J., Sunderland K.D., Fenlon J., Skervin D. \& SyMONDSON W.O.C. 2005: Detection of secondary predation by PCR analyses of the gut contents of invertebrate generalist predators. - Mol. Ecol. 14: 4461-4468.

SPSS 2010: Ibm Spss Statistics 19 Core System User's Guide. SPSS inc., Chicago.

StubBs A.E. \& Falk S.J. 2002: British Hoverflies: An Illustrated Identification Guide. British Entomological and Natural History Society, Reading, $469 \mathrm{pp}$.

Sunderland K.D. 1988: Quantitative methods for detecting invertebrate predation occurring in the field. - Ann. Appl. Biol. 112: 201-224.

SyMONDSON W.O.C. 2002: Molecular identification of prey in predator diets. - Mol. Ecol. 11: 627-641.

Thomas A.P., Trotman J., Wheatley A., Aebi A., Zindel R. \& Brown P.M.J. 2012: Predation of native coccinellids by the invasive alien Harmonia axyridis (Coleoptera: Coccinellidae): Detection in Britain by PCR-based gut analysis. Insect Conserv. Diver. 6: 20-27.

Traugott M., Zangerl P., Juen A., Schallhart N. \& Pfiffner L. 2006: Detecting key parasitoids of lepidopteran pests by multiplex PCR. - Biol. Contr. 39: 39-46.

TRILTSCH H. 1999: Food remains in the guts of Coccinella septempunctata (Coleoptera: Coccinellidae) adults and larvae. Eur. J. Entomol. 96: 355-364.

WARE R.L. \& MAJERUS M.E.N. 2008: Intraguild predation of immature stages of british and japanese coccinellids by the invasive ladybird Harmonia axyridis. - BioControl 53: 169-188.

Weber D.C. \& Lundgren J.G. 2009: Detection of predation using QPCR: Effect of prey quantity, elapsed time, chaser diet, and sample preservation on detectable quantity of prey DNA. - J. Insect Sci. 9: 41.

Wells P.M. 2011: Intraguild Predation by Harmonia axyridis: Effects on Native Enemies and Aphid Suppression. PhD Thesis, Darwin College, Cambridge University, $189 \mathrm{pp}$.

Zaidi R.H., JaAl Z., Hawkes N.J., Hemingway J. \& Symondson W.O.C. 1999: Can multiple-copy sequences of prey DNA be detected amongst the gut contents of invertebrate predators? - Mol. Ecol. 8: 2081-2087.

Zhang D.X. \& Hewitt G.M. 1996: Assessment of the universality and utility of a set of conserved mitochondrial COI primers in insects. - Insect. Mol. Biol. 6: 143-150.

Received November 5, 2012; revised and accepted April 8, 2013 